\title{
CULTURAL VALUES IN THE NOVEL “THE LEGEND OF CONDOR HEROES” (SHEN DIAO XIA LÜ) FROM JIN YONG
}

\author{
Luo Ying \\ Universitas Negeri Jakarta, Indonesia \\ jenifferLuo@gmail.com
}

\begin{abstract}
The purpose of this research is to understand deeply about cultural values in the novel "The legend of Condor Heroes" from Jin Yong. This research uses qualitative method with structural semiotic approach. The results of this research showed the theme from this novel was about love, plot were progressive and dramatic, setting was in Dynasty of Zhong, and the point of view used third person. There were also found cultural values from semiotic aspects from Icon, indeks, and symbol they were independent, zhi (wise), control of emotion, $\mathrm{Li}$ (morality), Lian (pure heart), Ren (affection), Zhong (loyal), simplicity, Xiao (obedient), interflow with nature, accomplishing character, Yi (responsibility), praying, and obey rules of Budha.
\end{abstract}

Keywords: Novel; Cultural Values; Structural; Semiotic.

Literature is a form of several creative art works that can be used as a medium to convey ideas, theories and systems of human thought. It is a result of the imagination of an author who poured into the form of literature through language. The idea of an author is then compiled into an interwoven stories which are nteresting and meaningful that tell about various problems of life experienced seen by the author. Literature is also a reflection of life depicting social life. Literature was created to be utilized by the society. The values contained in literary works can give pleasure and moral teachings that can be taken as an advantage by the reader.

As an imaginary literary work, fiction offers a wide range of human problems, humanity, life and living. The author appreciate these problems earnestly which is then expressed through the medium of fiction in accordance with his views (Nurgiyantoro, 2007: 3). Fiction report various problems of human life in interacting with the environment, ourselves and God. Fiction is the result of the dialogue and also a reaction to the environment and the life of the author. Although a literary work is fictious, but it is not a mere illusion. It is a contemplation, appreciation of the nature of life and living. Therefore, in addition to fiction aims to provide entertainment it also has aesthetic purposes in the form of inner satisfaction also provides educational elements to the reader. The research in literature is necessary to know and see the relevance of the content of literary works to the community life. The values contained within literary works reflect the social reality and influence people's lives toward positive direction.

If it related to teaching and education, basically, literature have relevance to realworld problems that can be considered that teaching of literature can contribute much to solving the problem which is quite difficult to solve in the society. Therefore, in addition, its function is not just can be entertaining but also can teach something (Rene and Austin, 1989: 25). Literature thus able to become a medium of instruction 
in solving the problems that exist in the lives of people who also have a function as entertainment. In the education system, teaching literature should be accompanied by efforts to instill an insight into cultural understanding for learners. Cultural understanding serves to foster a sense of pride, self-confidence and a sense of belonging. Basically, some special knowledge about the culture of its own, becoming a characteristic, since it can deepen the introduction of the character and cultural identity. Therefore, the teaching of literature, if implemented correctly, then, the introduction of culture to students or learners can be established through literature.

The literary work is a work of real humans that contain an author's imagination in presenting the issues and events in human life that can be used as teaching materials. 文化是人类在社会历史发展过程中所创造的物质财富和精神财富的 总和, 特质精神财富, 如文学、艺术、教育、科学等. (中国社会科学院 语言 研究所 词典 编辑 室 编, 2012: 1318) "Culture is the material and spiritual wealth created in the process of development of human social history, characteristics of spiritual riches, such as literature, art, education and science, etc." , So it can not be denied that literature became one of the works that contain cultural values.

As we know, the cultural values consisting of conceptions of life in the minds of most citizens on matters they consider noble. (Koentjaraningrat, 1986: 85). In other words, the value of culture is the most abstract layer and broader in scope. On this level, it is a collection of ideas to conceive of things that are most valuable in society. Ratna stated that the literary work contains aspects of cultural, not individual. Therefore, from a novel we can know the cultural values that exist within a particular society, both positive or negative culture (Nyoman, 2009: 329). From this point, authors utilize the novel as a mean to preserve and maintain the culture.

One of the novel contains elements of cultural value is Novel "Pendekar Rajawali Sakti (Hanzi: 神雕俠侶, Hanyu Pinyin: Shen Diao Xia Lu)" which is a work of Jin Yong's martial arts novels, and is the second part of the trilogy Rajawali that is very thick of elements of classical Chinese culture. Among them: "The father of Bu-sing named Liok Lip-ting, both his lwekang (inner power) or gwekang (outsourced / physical) have reached a considerable perfect level, just, since childhood, both parents watching him very closely and forbids him dabbling in the world of kangouw, so that his name was not well known in the world of martial despite his ability is relatively in a high grade. "(Gan KL, 1993: 25). In this section, the author tries to convey the most basic cultural values of the culture contained in the novel Pendekar Rajawali Sakti. Gwekang term (inner power) is a form of exercise that must be learned and practiced to gain physical strength from within. This is learned by every Chinese people who want to learn kung fu. In other words, Gwekang is a process to obtain physical strength that require continuous exercise. In Chinese culture, kungfu is a skill that is entrenched which later evolved into the art of the sport which is beneficial to health. Liok-Lip-ting, described as a humble figure. Despite having a high level in martial art, he was not involved in the martial world.

In Indonesia, this story is also known by the title of Sin Hiap Tiauw Lu (Hokkien dialect). In the English version of the novel it is titled The Return of the Condor Heroes, translated by GAN K. In Indonesia it is known as "Pasangan Pendekar Rajawali Sakti". The novel was first published on May 20, 1959 in the Ming Pao newspaper for 3 years.

In this study, researchers chose Structural and semiotic as methods used in analyzing novel Pendekar Rajawali Sakti works by Jin Yong. It is based on the theory 
that structural semiotic studies may reveal aspects of structural and cultural values in a novel. Structural aspects include the intrinsic elements of the novel: the theme, plot, characterization, setting and viewpoints. The semiotic analysis in the form of meaning towards signs, icon, index and symbol. Semiotic structural approach in studying the cultural values in a literary work has been done by many previous investigators.

\section{METHOD}

This type of research used is a qualitative study with content analysis method or analysis of the content through a structural approach semiotics. Through content analysis method we will know what is happening in the environment of observation, such as what the participants' views, and what kind of events that occur in the background of the study. (Emzir, 2010: 174). In addition to these methods, the structural approach of semiotic is also used in this study in which the approach can provide an understanding of the cultural aspects that are not only seen from the structural aspects such as themes, character and characterization, point of view, plot, and setting of a story but also can describe cultural values contained in a story with meaning semiotic signs such as icons, indices, and symbols which are types of designations meaning issued by Pierce.

Content analysis method with structural semiotic approach is believed by the author to provide a deeper understanding of the intrinsic elements in the novel Pendekar Rajawali Sakti and cultural values contained in them.

\section{RESULTS AND DISCUSSION}

Characters and Characterizations

In the novel Pendekar Rajawali Sakti there are many figures that play a role in the story of the martial arts, but the main character in that role is Yang Guo and Xiao Longnu who is the protagonist. Besides them, other characters or character extras who also play a major role in the novel Pendekar Rajawali Sakti is Mouchou and Jin Li Fa Lun Wang who are antagonists. In addition there is also the main character in the novel companion characters who also provide a considerable role to make the course of the novel Pendekar Rajawali Sakti increasingly attractive. Based on the opinion of Jones in Nugriyantoro that the characterizations are painting a clear picture of someone featured in the story. (Burhan, 2007: 165). Based on the results of the research aspects of the characterizations or characters in this novel are also found cultural values of the protagonists and the warrior including the value of struggle, dearest family, and a tender heart

Here is a discussion of the characterizations of each character in the story:

\section{Yang Guo}

In his childhood, Yang Guo or in terms of Indonesian known as Yo Ko was a jovial figure of a child and always eager. This novel analytically describes the behavior of little Yang Guo who is cheerful and signifies the beginning of the story in the novel Pendekar Rajawali Sakti. 
“就在这时，一个衣衫褴褛的少年左手提着一只公鸡，口中唱着俚曲，跳 跳蹦蹦地过来，见窑洞前有人。叫到:‘喂，你们到我家里来干吗？””

"At this time, a boy with clothes torn, his left hand raised rooster, singing and walking cheerfully, jumping, he saw a lot of the crowd in front of his house and shouted what are you doing in my house?" (Hal.38)

Since his childhood Yang Guo is not subject to regulations which he said is not good. Until he grows up, this character is shown with his loyalty and determination to continue to love and want to marry Xiao Longnüe although the customs of their ancestors is not allowed. Yang Guo thought that just to maintain the good name of the family why their love become forbidden? The dramatic character of Yang Guo illustrated in the following quote.

杨过凝视着小龙女的眼，说道: “当年重阳先师和我古墓派祖师婆原该好 好结为夫妻, 不知为了什么老什子古怪礼教、清规戒律、弄得各自遗恨而终 , 咱俩今日便在重阳主师的座前拜堂成亲, 结为夫妇, 让咱祖师婆婆出这口 恶气。

"Yang Guo Xiao's look at the eye of Longnüe and saying: at that time, our master, Chong Yang should have married the Ancestors ancient tomb, somehow the sake of rules and regulations that curb, so that they may regret it forever. This time we deliberately got married in front of the headstone of master Chong Yang to help our ancestors vent their emotions "(hal.968)

The quote above also portrayed cultural values which the character Yang Guo who respects the ancestors that are the hallmark of classical Chinese culture values. Xiao Longnu

Xiao Longnu or known in Indonesia as Bibi Long is a lover and a teacher of Yang Guo, a pupil of the Party of Ancient Tombs. Her role as the teacher and lover of Yang Guo is the thing that makes this story interesting.

Their relationship is opposed by many rules in the world of martial art, including the tradition of their fathers. Yet many of Xiao Longnüe properties that make it special in this novel that once made him so beloved by Yang Guo.

In this novel, Xiao longnüe is known as a beautiful young girl, but even though he does not like mostly pretty girls due to its indifferent and cold. Analytically and dramaticly the character of Xiao Longnu can be seen in the following excerpt.

杨过抬起头来，与她目光相对，只觉这少女清丽秀雅，莫可逼视，神色间 却冰冷淡漠, 当真洁若冰雪, 却也是冷若冰雪, 实不知她是喜是怒, 是愁是 乐。

"Yang Guo Xiao turned his head toward Longnue, he feels that this teenage girl is sweet and beautiful, but he can not be looked at closely, her expression cold and aloof as clear and flat as ice so it is unknown whether he is angry or happy" (hal.140) Mociu Li (Li Mouchou)

Known as the Goddess of Snakes, martial sister of Xiao Longnu, expelled after falling in love with a man who does not love her back. She is rampant in the jungle martial cruelty.

Although she is the sister of Xiao Longnu but has a much different nature from her. Li Mouchou is known by his martial prowess with cruel character. Analytically can be seen in the following excerpt.

"道姑 名叫 李莫愁, 外 后 '赤练仙子', 武功 既 高, 行事 又 是 心狠手辣. ' 
"This female warrior named Li Mouchou, also known as the Goddess of snakes, great kungfu, cruel and evil character" (p.12)

\section{Fa Lun Jin Wang}

The great masters of Tibet, became the principal advisor of Mongolia Empire. In an effort to become a leader in a meeting of the martial jungle fighters he was defeated by Yang Guo and Xiao Longnu. He does not accept the defeat which resulted in his failing to be the leader of the martial world.

Master Jin Lun continues to revenge against them and always intend evil to them. Master Jin Lun is known for its extensive knowledge.

金轮国师胸中渊博, 浩若湖海于中原名家的武功无一不知.

"Master Jin Lun has extensive knowledge, no one does not know about the famous kung fu in Zhong Yuan central plains" (hal.417)

Kwee Cheng

Kwee Cheng is the adoptive father of Yang Guo who always teach goodness and reminding if he made a mistake. although he is one of very famous warrior for most people but he still suave in his family. He was very fond of his wife. This proves the value of Chinese culture Ren (compassion) (Ruilin, 1999: 34), which is owned by Cheng Kwee.

“郭靖明白爱妻脾气，每当她无理取闹，总笑笑不理。倘若黄蓉恼得狠了 , 他就温言慰藉, 逗得她开颜为笑方罢。”

"Kwee Cheng understand the nature of his wife, every time his wife looking for a problem he just smiled and did not enter into the heart, if Huang Rong furious, he will entertain he with a soft-spoken until he laughs" (p.26).

\section{Zhou Botong}

One character who would have been nice for people who see is Zhou Botong or in Indonesia more famous by the term Bocah Tua Nakal. He was known as a person who is always laughing and having fun besides Zhou Botong known to be very pleased with a small child. Zhou Botong life is full of happiness and laughing. Whatever he thinks is fun. He is ignorant, full of humor and not serious. Zhou Botong had a penchant for work on people and he enjoyed it. He does not really care what's right or wrong (a little postmodern), is not too concerned with things that are serius.

\section{Background}

Structural analysis of the background to the novel Pendekar Rajawali Sakti is divided into three sections: the background of the place, time, and social. (Burhan, 2007: 227). Based on the background there is an element of culture form of social and political system that is part of the value of classical Chinese culture. This can be seen in the novel that the majority are in the dynasty or kingdom so that it can be said that China's social system society adopts a kingdom.

The story in this novel began in the Song Dynasty, City of Jiaxin which is the birthplace of one of the main characters, Yang Guo. It can be known from the quote of the following story.

"当时南宋 理宗 年间, 地处 嘉兴 南湖. 当时 嘉兴 属于 两浙 路 秀 州."

"In the song dynasty in southern Jiaxin river. At that time the city Jiaxin including town area Xiu Liang Zhou Zhe lu "(p.5) 
After discussing the background of place, the next step is to discuss about the background of the time. The first background of time in this novel is at midnight when Yang Guo wanted to quietly slipped away out to meet his master considered wicked and cruel.

“杨过与柯镇恶同睡一房, 到得中夜, 他悄悄起身, 听得柯镇恶鼻鼾呼呼 , 睡得正沉, 便打开房门, 溜了出去。。。。。”

"Yang Guo shared a bedroom with Ke Cheng E, until midnight he then secretly get up, heard the sound of snoring Ke Cheng $E$ was fast asleep and then he opened the exit" (p.57).

Plot

Further structural analysis is the analysis of the plot. Plot is a sequence of events, each event is connected in cause and effect, the incident caused by another event or events caused the event one another. (Esti, 2013: 71). In this study, analysis of plot used in the novels Pendekar Rajawali Sakti are five stages plot by Loban. The plot of the first stage is the exposition which is an initial stage of a story. The initial stages of the plot of the story begins with an introduction to the place and time, the Song dynasty.

"Song-li-Cong government in the Song dynasty, in the Oh-ciu, Kanglam area, there is a small town, named Leng-oh-tin. The time was near mid-autumn, the leaves of lotus begin to dry, solid lotus. At the small river edge of the small town five little girls were in a small boat singing and frolic with fun while rowing a boat to pluck lotus seeds. Among the five little girl aged three or less five dozen, two others were only eight or nine years "(H.1)

\section{Viewpoint}

Subsequent analysis is the analysis of point of view in this regard is the analysis of novel Pendekar Rajawali Sakti. The viewpoint is a term used in the twentieth century were used to design the views of a story that is generally divided into two things: the first and third person. (Peter and Roger, 2006: 182). Viewpoints in this novel belongs to the category of third-person perspective that is both omniscient because the authors are beyond the story so free to tell everything connected with the character, and displays the characters in the name of individuals or the personal pronoun. This can be seen in the following excerpt.

“公孙谷主本来疑心这六人与老顽童是同路人，后见潚湘子与他性命相搏 , 国师、尹克西、杨过、尼摩星、麻光佐各式绝技攻打, 倒颇有相助自己之

意, 各人武功不弱, 于是拱手道: ‘小弟有一件不情之请, 不知六位能予俯允 否?”

"Chairman of the valley Gong Sun was at first suspicious of these six people are in line with Zhou Botong then viewed Xiao Xiang Zi quarrel with him. Master Jin Lun, Yin Ke Xi, Yang Guo, Mo Ni Xing, Ma Guang Zuo fighting each other with their respective skills are unique. It seems that there is a desire to help me, everyone is not weak in the field of kung fu, and then he hands gripping one fist on her chest to show respect and said: there is un unworthy plea either if you are willing to accept? (P. 591)

Theme

Further structural analysis is an analysis of the themes in the novel Pendekar Rajawali Sakti. The theme is the foundation or the meaning of a story. Analyzing a 
theme in literature is necessary to advance the knowledge of the plot, characterizations, and dialogue contained in the story. (Suroto, 1989: 158).

Based on previous descriptions in the form of plot, characterizations, events, and dialogue in the novel that has been analyzed, it can be drawn a conclusion that the theme of the novel is a romance of Pendekar Rajawali Sakti. Further detail may be mentioned that the theme of the novel is the story of the struggle and the fidelity romance between Yang Guo and Xiao Longnu who should wait for 16 years because many of the barriers to their love that in the end they were happy together.

In addition, although the majority of the story tell about romance, but the novel that many also contains the values of struggle which is the value of classical Chinese culture that can be used as a lesson for today both for the Chinese and other nations.

Cultural Values in Relation between Man with himself, Man with Another Man, and Man with Nature from the Aspect of Semiotics.

This section is a discussion of cultural values in relation of man with himself, man to man, and man and nature from the aspect of semiotics. This section, described semiotic icons, indices, and symbols of aspects of human cultural values in conjunction with ourselves, human beings with other human beings, and human beings and nature.

Semiosis in Human Relations with himself

Before reviewing about semiosis signs of aspects of the cultural values of mankind's relationship to himself in the novel Pendekar Rajawali Sakti, are explained beforehand that the public views China since ancient basically adhere to the belief Tri Dharma. China in the belief Tri Dharma believes to Confucianism or three teachings of Confucianism, Taoism, and Buddhism.

Thus the author examines the relationship between semiosis of self by the three aspects. Confucius taught to be diligent in managing science. (Youlan, 2000: 44) One of the culrural values that can be seen in the following excerpt:

“黄蓉并不教杨过练武，只教他读书识字，课本乃是《论语》和《孟子》

，从《论语》的头一篇，即《学而》中的‘子曰：学而时习之，不亦说乎？有 朋自远方来, 不亦乐乎? '开始, 一直到最后, 学完了《论语》, 又学” "孟子 " (p. 77)

"Huang Rong did not teach kungfu to Yang Guo. He just teach him to read and recognize words, textbooks namely Lun Yu and Mengzi. of the first lessons Lun Yu (xue 'er). Confucius said: the knowledge they have learned and repeated over and over isn't it fun? There is a good friend who come from afar isn't it a pleasant thing? ". (Hal.77)

The above sentence indicates that the process of learning of Yang Guo is before learning kungfu he must first learn the lessons of kindness so that Yang Guo did not follow footsteps of his father who had a great kung fu moves but does not have good behavior. This is in line with Chinese cultural values that teach about kindness.

In learning kungfu we also learning about the nature not to be arrogant and humble. In the following excerpt it can be seen clearly.

"既在这墓中住, 就得修心养性, 绝了与旁人争竞之念."

"If you had lived in this cemetery, to keep the heart and character, avoid the desire to fight with others" (144) 
Semiotic mark in the above quotation is to nourish the heart and character to avoid a fight with others. One with nature. Characteristic of Chinese culture will always figure out a unified way between humans and the heavens, ethically rooted cultural patterns of self, the family spread to the society and the Universe, until finally able to convey the state of human nature and adjust to each other. (Ziquan, 2008: 72)

Representament in the above quote was keep your hearts and characters while the object is to avoid the desire to fight.

Representamen relationships and objects form a relationship index. Interpretan of the above quote is that despite having a great kungfu later but humility must be kept and when you can avoid the enemies better to avoid than to fight it. Cultural values contained in these quotations is humility (Lian). (Beijing Da Xue Xue Zhe Jiao Yan Shi, 2001: 21)

Semiosis in Human Relations with other humans

The semitics sign and aspects of cultural values in human relationships with other human beings can be seen in the following quotations.

"娘子, 陆家满门今日倘若难逃一死, 也让咱们死得不堕了兄嫂的 威名."

"Lu Liding said: dear, today we can not evade our mortality but the important thing today we do not damage the reputation of our brother and sister-in-law". (P.14)

In classical Chinese culture most people will place great importance on clan or their families exceed even their lives. Semiotic mark in the above quotation is not able to avoid death. As will be able to connect with the term "Xiao-filial behavior", each family member must maintain the reputation of the family. Representamen in the above quote was not able to avoid death while the object is not damaging the reputation of his brother and sister-in-law.

From the representamen and the object, the relationship is in the form of index. Interpretan of semiotic signs above is at the time of the warrior feel his or her life almost reach the end, they remains concerned, and in view of his family.

This indicates the existence of cultural value, that altough they could not keep themselves well but they have to maintain the good name of the family. It is at once a sign of cultural values in human relationships with other human beings.

Other semiotic sign can be seen in the following excerpt.

“陆立鼎：待要跃上斯拼，却想对方年幼，又是女子，可不便当真跟她动 手。。”

"Suddenly do not know how to deal with it, he is ready to jump up to attack but hesitate due to the opponent is a woman and still young." (Pg.16).

Semiotic mark in the above quotation is ready to attack opponents but hesitated because his opponent is a woman, and still young. Values are related to "Li" Deserving, the noble qualities that one's personal morals, behaviour, and manners. Representamen in the above quotation is ready to jump up to attack the opponent while the object is woman and still young.

The relationship between representamen and the object is a form of an index. In which a causal relationship or causal. Figures or warriors in the novel would not attack because his opponent is a woman, and still young so he thought better not to attack the girl. 
Interpretan in the above quote that the youth in the above quote does not want to fight a girl especially the young girls. Thus it can be said that in these quotations there are cultural values between humans with other humans that is a lesson for men to respect and protect women especially when they are young.

Semiosis of relationship between Man and Nature

Subsequent semiotic analysis is the human relationship with nature that can be seen in the following quotes:

“杨过受人欺侮多了，见这瘦马如此痛苦，这一鞭鞭犹如打在自己身上一

般, 胸口一酸, 泪水几乎欲夺目而出, 双手叉腰, 站在路中, 怒道: ‘那汉 子，你鞭打这马干吗？’。。。。。杨过大怒： ‘你再打马，我杀了你！’那 瘦马模样虽丑, 却似甚有灵性, 见莽汉遭打, 纵声欢嘶, 伸头过来在杨过腿 上挨挨擦擦, 甚是亲热。”

"Yang Guo has been widely treated arbitrary, suddenly he saw a thin horse so miserable, occasionally beaten with a stick, Yang Guo's feeling suddenly feel bad till the tears almost came out, then he stood in the middle of the road shouted angrily, why did you hit him? If you hit this horse I will kill you ... ..Although it's a skinny and seem unattractive horse but has a high intelligence, when it saw Yang Guo beat that rude man, it is yelling as if the horse was happy "(h.365)

Semiotic mark in the above quotation was he saw a thin horse that continues to hit and then he threatened to kill the person who hit the horse proficiency level. Representamen of the quote is that he saw a skinny horse continued to hit while the object is I will kill you.

The relationship between the sign and the object is a causal relationship that fall into the category of index. He saw the horse was beaten so he became angry. Characteristic of Chinese culture will always figure out a unified way between humans and the heavens, ethically rooted cultural patterns of the self, the family spread to the community and the Universe, until finally able to convey the state of human nature and adjust to each other. (Ziquan, 2008: 72) Animals also includes one member of nature, interpretan in these quotations is Yang Guo did not like seeing animals tortured or being hurt. Hence the value of culture in these quotations is do not hurt the animal.

杨过道: “姑姑, 这是咱们练功的好所在。你在这边, 我到花从那一边去 。咱俩都解开了衣衫, 但谁也瞧不见谁。岂不绝妙? ’小龙女听了大觉有理。 她跃上树去, 四下张望, 见东南西北都一片清幽, 只闻泉声鸟语, 查无人迹 , 却是个上好的练功所在。。。,

"Yang Guo said; This is a good place to practice kungfu among the flowers, if we both exercise then there won't be anyone who see us and from the south east, north, west to north it's scenery scenic no one sees its place as well as the peace and quiet was only the sound of water and birds , this is a good place to practice kungfu "(hal.187)

Semiotic mark in the above quotation is a great place kungfu training among the flowers. Representamen of quotation above is a great place kungfu exercises while the object is flowers. Their relationship is symbolic because the flowers are seen as representing a quiet place for training. 
Interpretan of semiotic sign above is that natural conditions such as flowers have harmony with humans which can help people to become more confident in doing meditation or exercise kungfu. Cultural values in these markers represent a harmonious relationship between humans and nature.

Still in the same quotation, next semiotic mark is a quiet place only the sound of water and birds. Tao became the mover of the universe, namely as a rule, rhythm, and the driving force of all nature, as well as the principle of a stylist who is behind all that exists. The representamen is a quiet place while the object is the sound of water and birds. Relations were formed due to iconic sound of water and birds are thought to have in common with a quiet atmosphere.

Interpretan of semiotic sign illustrates that the sound of water and birds is a sign of tranquility that is a great place to exercise. Cultural values in the novel is the balance between man and nature that uses the sound of water and birds as their sedatives.

Semiosis of relationship between Man and God

Based on the findings, cultural values relating to man's relationship with God are discovered. According to Djamaris Cultural values in the relationship with God is a value of piety, like to pray, and surrender to the power of God. (Edwar, 1993: 6). The cultural value of this research is to reduce desire, among others, pray, and obey the teachings of Buddha. Here are excerpts of the cultural values.

过了片刻, 只听郭衰道: “老天爷, 我第一个心愿, 盼望爹爹妈妈率领人 马, 会同众位英雄好汉, 杀退来犯的蒙古兵, 襄阳百姓得保太平。。。。。 。我第二个心愿, 盼望爹㸘妈妈身子安泰, 百年长寿, 盼望爹娘事事如意称 心。。。。。我第三个愿望, 盼望神雕大侠杨过和他夫人小龙女早日团聚 , 平安喜乐。”

A moment later, suddenly Guoxiang spoke: "Lord, my first desire is, may mom and dad ordered the troops, along with the hero, to attack the enemy of Mongolia, the people of Yang Xiang can always be safe through. My next desire is may father and mother healthy , long life and can satisfy the desire ...... third desire is may Pendekar Rajawali Sakti Yang Guo Xiao as quickly rejoined Longnue, may they are healthy and happy. "(p. 1269)

On the citation, it is described about cultural values which are related to the Lord that is prayer. It is clearly visible that one of the characters in the story ask the Lord to move his parents against the Mongolian safely and and longevity. In the theory of semiotic, sign used in the above quotation is in form of an index.

"佛家 有 好生 之德, 岂能 见死不救"

Buhdda appreciate life, favored the people, a nature of not to kill, it is forbidden seeing people in distress without saving them. (P. 1097)

In the quote above it is described about cultural value of obeying the precepts of Buddhism such as not killing and always helping people in distress. They reflect the cultural values of mankind's relationship with God. Based on the theory, then the relationship goes into the sign in form of index.

"国人 习俗, 向来 上坟扫墓, 若非 清明, 便是 重阳, 此 所谓 春秋 两 祭" 
Customs of the people, is used to come to the cemetery to honor the dead or sweep the grave ---- visiting someone as a tribute or memorial, if not (Qingming) Cengbeng ---- Chinese feast for the pilgrimage to the tomb, meaning Ninth Festival (the 9th day of the 9th lunar month). It is said to be praying of spring and autumn. (P. 1397)

The quote above showed the cultural values associated with worship. It can be seen on the quote "It is said to be praying of spring and autumn". From these quotations it appears that at the time of classical China the activity of worship showed by coming to the funeral or a temple to honor the ancestors.

“天苍苍兮临下土，胡为不救万灵苦? 万灵日夜相凌迟，饮气吞声死无语 。仰天大叫天不应, 一物细琐徒劳形。安得大千复混沌, 免教造物生精灵。

The chaos is caused by war in several consecutive years and broken families everywhere. Qiu Jichu as a monk would believe there are gods who could save the people but feel sorry to see that the condition does not change while he could not do anything. (P. 83)

The quotation above shows the cultural values associated with the belief in gods. In the days of the classic China the society have the belief in the power of gods that could help people out of trouble. To ask for help to gods, they came to the temple and prayed to the gods by providing an incense or offerings. Based on the theory, it is a form of icons.

\section{REFERENCES}

Beijing Da Xue Zhe Xue Xi Zhong Guo Zhe Xue Jiao Yan Shi. Zhong Guo Zhe Xue Shi. Beijing: Beijing Da Xue Chu Ban She, 2001

Childs, Peter dan Fowler, Roger, The Routledge Dictionary of Lierary terms. New York: Routledge, 2006

Emzir, Metodologi Penelitian Pendidikan Kuantitatif dan Kualitatif. Jakarta:PT Raja Grafindo Persada, 2010

Djamaris, Edwar. Nilai Budaya dalam Beberapa Karya Sastra Nusantara: Sastra Daerah di Sumatera. Jakarta: Pusat Pembinaan dan Pengembangan Bahasa Departemen Pendidikan dan Kebudayaan, 1993

Feng YouLan. Zhong Guo Zhe Xue Shi .Hua Dong Fan Da Xue Chu Ban She, 2000.

Gan K.L, Pendekar Rajawali Sakti: Jilid 1. Semarang: Panca Satya, 1993

Guo Ruilin. Zhong Guo Chuan Tong Wen Hua Yu Zhong Xue Yu Wen (Changsha: Hu Nan Shi Fan Da Xue Chu Ban She, 1999.5

He Ciquan. Zhong Guo Wen Hua Liu Jiang (Beijing: Beijing Da Xue Chu Ban She, 2008.

Ismawati, Esti. Pengajaran Sastra, Yogyakarta: Ombak, 2013 
Koentjaraningrat, Pengantar ilmu Antropologi .Jakarta: Penerbit Aksara Baru, 1986

Nurgiyantoro, Burhan. Teori Pengkajian Fiksi. Yogyakarta: Gadjah Mada University Press, 2007

Ratna, Nyoman Kutha. Stilistika: Kajian Puitika Bahasa, Sastra, dan Budaya.Jakarta: Pustaka Pelajar, 2009

Suroto, Teori dan Bimbingan Apresiasi Sastra Indonesia .Jakarta: Erlangga, 1989

Wellek, Rene dan Warren, Austin, Theory of Literature, Jakarta: PT Gramedia, 1989

中国社会科学院语言研究所词典编辑室编. 现代汉语词典. 商务印书局出版社 , 2012

Zhong Guo She Hui Ke Xue Yuan Yu Yan Yan Jiu Suo Ci Dian Bian Ji Shi Bian. Xian Dai Han Yu Ci Dian. Shang Wu Yin Shu Ju Chu Ban She, 2012 